Central Washington University

ScholarWorks@CWU

6-2015

\title{
Using Satellite Image Analysis for Locating Prehistoric Archaeological Sites in Alaska's Central Brooks Range
}

Robert Hickey

Central Washington University, Robert.hickey@cwu.edu

J. Keeney

University of Alaska, Fairbanks, joseph_keeney@nps.gov

Follow this and additional works at: https://digitalcommons.cwu.edu/geography

Part of the Archaeological Anthropology Commons, and the Geology Commons

\section{Recommended Citation}

Keeney, \& Hickey. (2015). Using satellite image analysis for locating prehistoric archaeological sites in Alaska's Central Brooks Range. Journal of Archaeological Science: Reports, 3, 80-89.

This Article is brought to you for free and open access by the College of the Sciences at ScholarWorks@CWU. It has been accepted for inclusion in Geography Faculty Scholarship by an authorized administrator of ScholarWorks@CWU. For more information, please contact scholarworks@cwu.edu. 


\title{
Using satellite image analysis for locating prehistoric archaeological sites in Alaska's Central Brooks Range
}

\author{
Joseph Keeney ${ }^{\mathrm{a}, \mathrm{b}, *}$, Robert Hickey ${ }^{\mathrm{c}}$ \\ a National Park Service, 4175 Geist Rd., Fairbanks, AK 99709, United States \\ b Department of Anthropology, University of Alaska Fairbanks, 303 Tanana Loop, Bunnell Building Room 405A, Fairbanks, AK 99775-7720, United States \\ c Department of Geography, Central Washington University, 400 E. University Way, Ellensburg, WA 98926, United States
}

\section{A R T I C L E I N F O}

\section{Article history:}

Received 3 February 2015

Received in revised form 18 May 2015

Accepted 30 May 2015

Available online $\mathrm{xxxx}$

\section{Keywords:}

Satellite imagery

Multi-spectral analysis

Archaeology

Arctic

Alaska

Prehistoric sites

Hunter-gatherers

Site reconnaissance

Site prospection

\begin{abstract}
A B S T R A C T
In this pilot study, we apply satellite image analysis to archaeological site prospection in Alaska's Brooks Range. Our goal was to test whether satellite remote sensing, which has been successful in locating large archaeological features associated with sedentary peoples, could be applied to arctic interior sites associated with mobile hunter-gatherers. In particular, we strove to develop a relatively straightforward and inexpensive model using existing data which could be used to help guide archaeology surveys. Using 1-m resolution IKONOS imagery of Lake Matcharak along the upper Noatak River, we produced a Normalized Difference Vegetation Index (NDVI) and tasseled cap transformation of the study area and stacked these five vegetation indices into one image. We then applied unsupervised and supervised classifications to the image first, to test for the presence of a site-specific spectral class and second, determine the nature of that class. Through a visual analysis of the unsupervised classification, a spectral phenomenon was seen to co-occur with archaeological sites in the study area. The supervised classification provided a high-resolution land cover map used to identify the signature as the ecotone between un-vegetated sediments and dense willow (Salix sp.) stands. Dense willow stands along the Lake Matcharak shore visually correlate with most of the known archaeological sites, possibly reflecting landform and/or vegetation characteristics that would have appealed to past inhabitants. The methods described here could contribute to building better survey strategies and archaeological predictive models for elsewhere in the Brooks Range and Alaska.
\end{abstract}

Published by Elsevier Ltd.

\section{Introduction}

In terms of logistics, effort, time, and money, archaeological surveys are often costly (Giardino and Haley, 2006). Alaska is an expansive region where research areas are often extremely difficult to access and opportunities to collect data are limited. Land managers thus expend precious and dwindling resources for costly surveys that result in very little representative sampling. One avenue for addressing this issue is to develop survey strategies to focus on archaeologically productive areas, and satellite image analysis is a relatively low cost method with great potential to contribute to these needs.

Archaeologists have been using satellite technology over at least the last three decades to study past cultural landscapes. During this time, spatial and spectral resolutions improved, imagery became cheaper and more accessible, and analysis software packages became more powerful and user-friendly. In turn, multispectral variables that are undetectable by conventional field survey or aerial

\footnotetext{
* Corresponding author at: National Park Service, 4175 Geist Rd., Fairbanks, AK 99709, United States.

E-mail addresses: joseph_keeney@nps.gov, jwkeeney@alaska.edu (J. Keeney), rhickey@cwu.edu (R. Hickey).
}

photos became more readily available, allowing new possibilities for site identification and predictive modeling (Lasaponara and Masini, 2011, 2012c; Parcak, 2009).

Very high (spatial) resolution (VHR) satellite imagery has been used successfully within the last 10 years to detect and analyze large anthropogenic landforms and structures. Beck et al. (2007) compared the ability to detect archaeological features in the Homs Region of Syria using Corona and IKONOS imagery. The authors relied on visual interpretation and some digital enhancement to contrast between natural and archaeological patterns. They found that an anthropogenic signature depends on environmental contexts and seasons, and that the two imagery types were best used together. Lasaponara and Masini (2007) and Masini and Lasaponara (2007) used Quickbird imagery to detect the outlines of buried medieval structures in southern Italy. The authors determined that feature detection depended on overlying soil and vegetation conditions, and required different spectral analysis methods to reveal features. De Laet et al. (2007) compared GIS, pixel-based, and object-based methods applied to IKONOS imagery for identifying Late Iron Age stronghold ruins in southwest Turkey. All methods successfully detected features, but the authors were unable to identify a unique shape or spectral class to characterize archaeological features. Visual interpretation proved to be most useful for detecting sites, but a spectral 
analysis could have been better if the archaeological remains were composed of materials different from the local landscape. Saturno et al. (2007) used VHR imagery to identify contemporary vegetation signatures linked to archaeological remains in Guatemala. Spectral signatures indicated vegetative stress related to decomposing Mayan lime plaster. Alexakis et al. (2009) applied several digital processing techniques to IKONOS and other satellite data to detect Neolithic settlement mounds in Greece. The authors found that the medium and high spatial and spectral resolution sensors were reliable to visually or spectrally detect these cultural features. Alexakis et al. (2011) expanded on this work by incorporating vector-based variables with imagery data to predict mound locations. Trier et al. (2009) experimented with methods for identifying ring-like crop marks related to Norwegian burial mound remains using Quickbird imagery. Oltean and Abell (2012) used a vegetation index to detect large buried features in Romania with multispectral Quickbird imagery. Recently, De Laet et al. (2015) apply imagery enhancement techniques to Quickbird imagery to distinguish road systems in Middle Egypt associated with limestone quarries by their period of use.

In addition to expansive and durable features, satellite image analyses have also been successfully applied toward small-size archaeological sites and features. For example, Buck et al. (2003) evaluated the potential for satellite remote sensing to identify obsidian and pottery surface artifact concentrations in arid areas of California and New Mexico. The authors found that the thermal-infrared properties of concentrated surface artifact scatters could be directly detected in contrast to local ground cover. Grøn et al. (2011) investigated cooking pit, road, house, and mound features in Norway using Quickbird imagery. The authors determined that spectral analysis could distinguish geochemical anomalies in the vegetative canopy, proxy indicators for the underlying archaeological features. After using Landsat imagery to identify gossans (iron caps) associated with mining in Yemen, Deroin et al. (2011) used Quickbird imagery to identify individual archaeological mining features. Luo et al. (2014) incorporated Worldview-2, Google Earth, and Ziyuan-3 imagery into a predictive model to identify high probability areas to survey for lost courier stations along the Han Great Wall in China.

Despite the reported success of satellite imagery to identify large cultural features associated with complex societies, published accounts of its application to small-size features, especially those associated with mobile groups, are rare in the literature. Additionally, there are few reports of satellite imagery analyses applied to American archaeology, particularly in Alaska. This paper attempts to address these gaps by investigating satellite imagery's potential for locating prehistoric Alaskan archaeological sites, specifically those associated with mobile huntergatherers in the Brooks Range. As most sites in this region are limited to small and often buried lithic scatters, we recognized the limitations for satellite imagery to detect individual features and artifacts directly; however, there was promise for identifying seasonal activity areas based on site-specific conditions in the current landscape. Modern land cover may provide proxy indicators for landscape conditions that appealed to past human occupants (Warren, 1990; Whitley, 2006) and/or soil chemistry that has been influenced by the underlying cultural materials (Brophy and Cowley, 2005; Giardino and Haley, 2006; Lasaponara and Masini, 2012a,c; Maxwell and St. Joseph, 1983; Parcak, 2009; Wilson, 1975).

We hypothesized that a spectral class would visually correlate with known archaeological sites in the study area given high-enough resolution imagery. The National Park Service (NPS) Alaska Region possesses large quantities of $1 \mathrm{~m}$, multispectral IKONOS data for parks throughout Alaska, making it ideal for being not only free but also compatible with methods applied elsewhere in Alaska.

We first generated and stacked five land cover indices used to produce an unsupervised classification of the study area. From this, we recognized a spectral class visually associated with known sites situated near the lake shore. We then collected field data and generated a high-spatial-resolution land cover map of the study area using a supervised classification. The supervised classification was used to identify the spectral phenomenon as a characteristic of willow (Salix sp.), most notably in dense stands above the well-drained, south-facing lake terraces. This association with willow could be the result of the continued presence of an important resource for fuel and raw materials or a vegetation type favoring topographic characteristics that also appealed to prehistoric inhabitants. The findings in this pilot study suggest that unsupervised and supervised classification techniques, when applied to VHR imagery, can be used to detect spectral characteristics of modern land cover that relate to prehistoric hunter-gatherers. These methods and findings can be useful for future predictive models and developing survey strategies that target high-probability areas for unknown sites, which is particularly useful for areas that are difficult and costly to access.

\section{Material and methods}

\subsection{Study area}

Lake Matcharak is located $350 \mathrm{~km}$ north of the Arctic Circle within Gates of the Arctic National Park in Alaska's Brooks Range (Fig. 1). The Brooks Range is the northern extent of the Rocky Mountains and forms a $180-200 \mathrm{~km}$ wide arc across northern Alaska from Canada to the Chukchi Sea. Glacial erosion in the uplifted sedimentary and metamorphic landscape left valley floor elevations at approximately $500 \mathrm{~m}$ and peaks ranging from 800 to $2400 \mathrm{~m}$. Climate in the Brooks Range varies from arctic in the north to subarctic in the south and from continental in the east and central areas to maritime in the west. Anaktuvuk Pass, the nearest town with the most comparable setting to Lake Matcharak, receives approximately $28 \mathrm{~cm}$ of precipitation and $160 \mathrm{~cm}$ of snowfall annually. Average Anaktuvuk Pass winter lows and highs are $-30{ }^{\circ} \mathrm{C}$ and $-22{ }^{\circ} \mathrm{C}$ and summer lows and highs are $3{ }^{\circ} \mathrm{C}$ and $16{ }^{\circ} \mathrm{C}$, respectively. Vegetation cover in the Brooks Range is sparse and limited to valleys and low hill slopes due to highly-erodible slopes, shallow soils, high winds, and harsh climate. The northern and western regions of the Brooks Range support a tundra biome with continuous shallow permafrost, poor drainage, and sparse vegetation while boreal forest populates valleys in the south-central and southeastern regions. Dwarf scrub communities dominate drier tundra regions with ericaceous species, mountain-avens, willow, and sometimes herbaceous species and fruticose lichens. Wetter areas contain mesic graminoid herbaceous communities but are dominated by sedges, willows, and sometimes mosses (Gallant et al., 1995).

Situated along the east margin of the Noatak River in a glacially carved valley, Lake Matcharak is approximately $200 \mathrm{~km}$ downstream of the river's headwaters at $67^{\circ} 45^{\prime} 00^{\prime \prime} \mathrm{N}, 156^{\circ} 12^{\prime} 50^{\prime \prime} \mathrm{W}$. The northwestsoutheast trending kettle lake is flanked by approximately $10 \mathrm{~m}$-high terraces along its east and west shorelines. Lake Matcharak is part of a glaciolacustrine landscape where a larger moraine-dammed lake formed during Late Pleistocene glacial retreat. After the Noatak River breached the moraine dam, the basin drained, and subsequent fluvial erosion resulted in the modern terraced landscape (Hamilton, 2009). The study area encompasses the land surface within $1000 \mathrm{~m}$ of the lake's shoreline (Fig. 2); it is dominated by sedge-dryas meadows and low willow, birch (Betula sp.), heather, and tussock shrub lands (AK I\&M Inventory Program, 2009). Caribou have been periodically sighted around the lake in the summer and are known to pass through the Brooks Range in greater numbers during the spring migrations north and again in the fall as they move south. Migratory water fowl including swans, loons, and ducks have also been sighted in and around Lake Matcharak in the summer. Pike and lake trout have been sighted swimming along the shallows of the lake, and grayling and burbot have been identified in a local archaeological context (Tremayne, 2011). Located $275 \mathrm{~km}$ west of the nearest road system and within national parkland, access to Lake Matcharak is limited to float plane, 


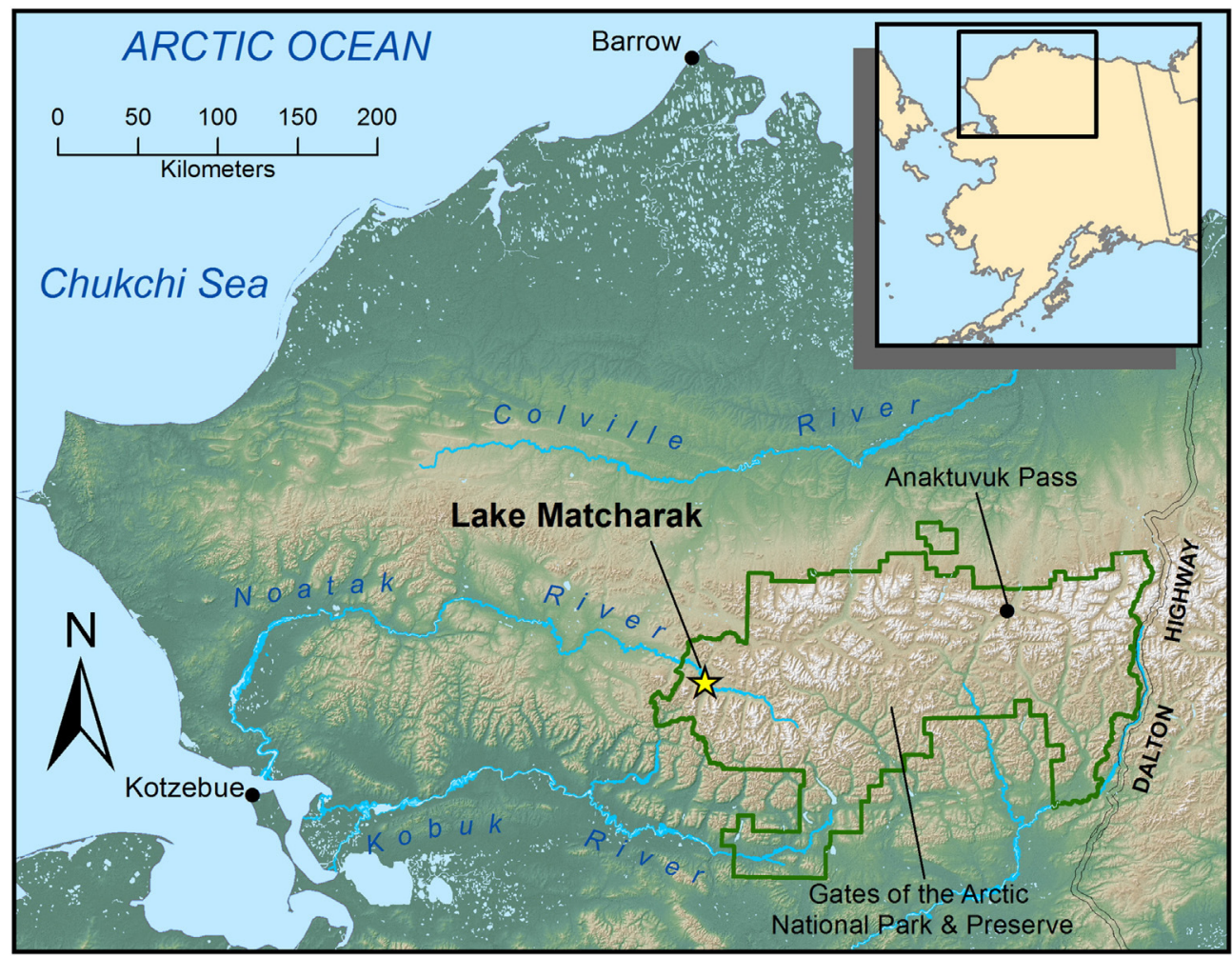

Fig. 1. Location of Lake Matcharak in Alaska's Central Brooks Range.

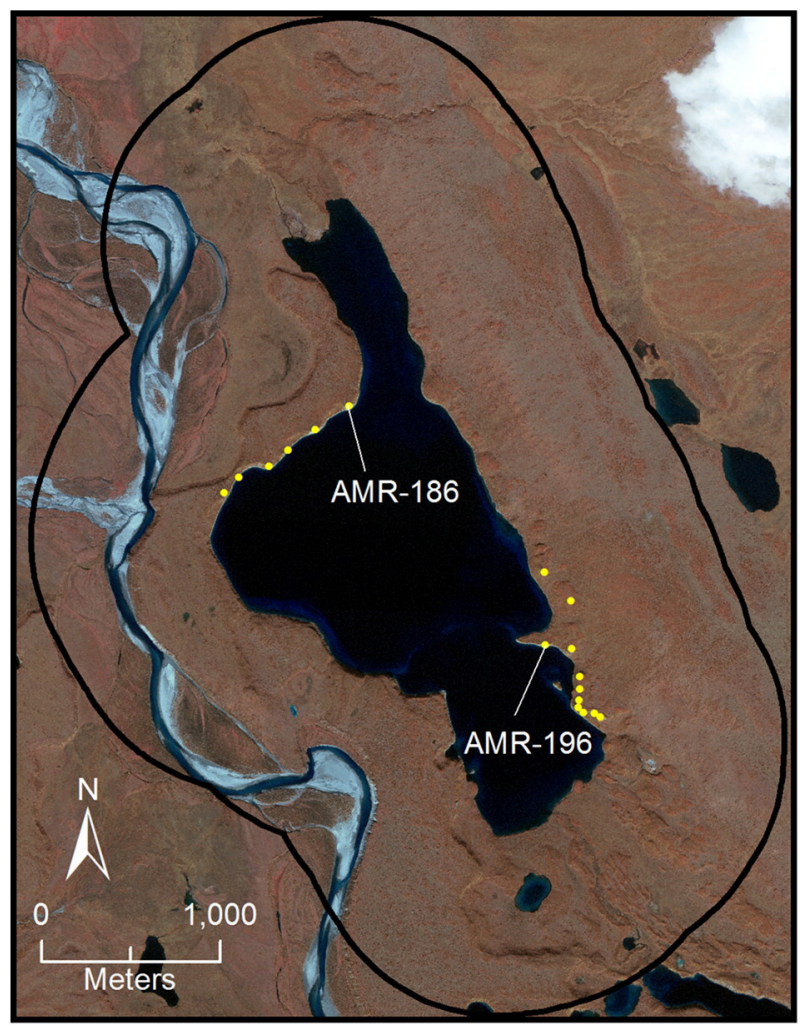

Fig. 2. Color infrared IKONOS image of Lake Matcharak. The line represents the $1000 \mathrm{~m}$ buffer that defined the study area. The yellow dots represent known site locations, most notably AMR-186 and AMR-196 which are discussed below. (For interpretation of the references to color in this figure legend, the reader is referred to the web version of this article.) non-motorized water craft, dogsled, and foot, making travel difficult and very expensive. Although federal lands, especially national wilderness areas, have more restrictive vehicle policies, most of Alaska is similarly difficult to access.

\subsection{Previous archaeological research in the area}

We selected Lake Matcharak for this study due to its welldocumented archaeological sites and the opportunity to collect field data for this project in the summer of 2011 (additional work during a planned excavation). Seventeen known archaeological sites are located near the shoreline (Fig. 2), primarily along terraces dominated by dense shrub willow. Subsurface tests uncovered flaked stone artifacts and well-preserved faunal remains. Currently, 38 radiocarbon dates from 8 sites reflect human occupations at Lake Matcharak as far back as $\sim 7000$ calibrated years ago. Due to the nearly continuous vegetation surrounding the lake, all sites were discovered through subsurface testing or terrace erosion. Cultural materials have been found approximately $15-100 \mathrm{~cm}$ below the ground surface, most frozen in permafrost.

Subsurface testing at two sites has expanded into block excavations with a wealth of information on past human land use in the area. The Matcharak Lake site (AMR-186) is located on a terrace in the northwest corner of the lake. Excavations in 2008 and 2009 revealed an abundance of well-preserved faunal remains, stone tools, and debitage along with several worked bone and antler artifacts and a potential tent ring distributed over at least $450 \mathrm{~m}^{2}$. The stone tools and radiocarbon dates span from $4010 \pm 40$ to $3430 \pm 40{ }^{14} \mathrm{C}$ BP and are indicative of the Denbigh Flint Complex of the Arctic Small Tool tradition (Giddings, 1951, 1964; Irving, 1964; Slaughter, 2005; Tremayne, 2011, 2015). The faunal assemblage at the Matcharak Lake site is dominated by caribou but also includes a range of large and small mammals, fish, and birds. Seasonal availability of some of these species and the absence of semi-subterranean (winter) dwellings suggest a spring through the fall occupation (Tremayne, 2011). The stone tool assemblage suggests 
a tool kit designed to maximize utility and transportability while minimizing production time, features suggestive of high-residentiallymobile people (Tremayne, 2015).

The Matcharak Peninsula site (AMR-196) is located above an eroding terrace on the peninsula in the lake's southeast corner. Excavations in 2010, 2011, 2013, and 2014 uncovered well-preserved and abundant faunal remains and lithics distributed over at least $1000 \mathrm{~m}^{2}$. A detailed analysis of both fauna and lithics from the Matcharak Peninsula site is currently in progress, but preliminary findings suggest that the faunal assemblage is dominated by caribou and/or Dall's sheep but also contains small mammals, fish, and birds. Although dates from two charcoal and one bone sample suggest a late prehistoric component at the Matcharak Peninsula site, the majority of dates from 16 bone specimens span from $6190 \pm 35$ to $3800 \pm 30{ }^{14} \mathrm{C}$ BP. These earlier dates, along with the presence of side-notched point bases and microblade technology, are characteristic of the Northern Archaic tradition (Anderson, 1988; Clark, 1992; Esdale, 2008; Workman, 1978).

\subsection{Data}

The project goal was to test if we could identify small-sized, short-term hunter-gatherer sites that are typically found in the Brooks Range based on modern land cover. This required multispectral imagery with spatial resolution that could adequately distinguish finegrained variations in land cover; IKONOS imagery met this requirement. While other VHR imagery might offer better spectral or spatial resolution, Alaska's National Park Service (NPS) regional office possesses large quantities (on the magnitude of tens of millions of acres) of IKONOS imagery for many of the Alaska national parks. In addition to being free of cost to us, if results were useful, the methods used in this pilot study could also be expanded to the larger geographic extent of imagery possessed by the NPS.

Geoeye's IKONOS-2 imagery records data in four multispectral bands: blue, green, red, and near-infrared. A panchromatic band was used to "pan sharpen" the $4 \mathrm{~m}$ resolution multispectral bands, resulting in a four-band multispectral image with a $1 \mathrm{~m}$ spatial resolution (Jensen, 2005, 2007; Lillesand et al., 2008). The IKONOS satellite acquired the cloud-free image on September 6, 2008 and was received by the authors pan sharpened and georeferenced to an accuracy of $\pm 10 \mathrm{~m}$ (Digital Globe, 2015).

Unlike many state offices of historic preservation, the Alaska Office of History and Archaeology defines a site as any number of artifacts separated by less than $50 \mathrm{~m}$. Therefore, the discovery of a single lithic flake constitutes a site and dispersion of more than $50 \mathrm{~m}$ delineates individual sites. The NPS administrative office in Fairbanks, AK provided a GIS file of all the known sites within the study area, which was generated from GPS waypoints (accurate to $\pm 10 \mathrm{~m}$ ) collected during NPS surveys between 2007 and 2011. Each point reflects the location of either a site datum or a single positive shovel test.

Following the unsupervised classification, we collected groundreference data to classify the study area land cover in July 2011. Due to the limited time allotted for this project during regular NPS fieldwork, we decided that GPS waypoints and photographs would be the most efficient way to quickly collect land cover data. We collected photos and waypoints from 61 locations using a 12.1 megapixel camera and a Garmin GPS (accurate to $\pm 10 \mathrm{~m}$ ). The camera provided adequate resolution to identify general vegetation communities out to approximately $50 \mathrm{~m}$. We sampled by roughly circling the lake, recording a GPS waypoint at approximately every $250 \mathrm{~m}$, photographing the immediate location and outwards in at least the four cardinal directions; we also logged each exposure's location and direction. We later converted the waypoints to a shapefile used to spatially reference homogenous vegetation communities in the photos to the IKONOS image.

\subsection{Analysis}

Our primary goal was to test whether or not a method for extracting spectral signatures generated from multispectral imagery would visually correlate with known archaeological sites in the study area. If successful, this method could be incorporated into future models to predict high-probability locations for unknown sites.

Working under the hypothesis that archaeological sites would be associated with land cover characteristics that are spectrally distinct from adjacent areas, we derived the spectral-based variables from the Normalized Difference Vegetation Index (NDVI) and tasseled cap transformation from the original imagery. These data allowed us to look for variability in the vegetation cover patterns related to spectral characteristics that otherwise might not be visible in the original 4 IKONOS bands. The NDVI output indicates the vigor of vegetation biomass by comparing the reflection of red (absorbed by chlorophyll) and near infrared (reflected from leaf cell structure) energy while helping to compensate for changes in illumination, surface slope, and aspect (Jensen, 2005, 2007; Lasaponara and Masini, 2012a; Lillesand et al., 2008). Variations in vegetation can reflect archaeological features affecting the overlying vegetation (Lasaponara and Masini, 2012a; Parcak, 2009). The tasseled cap transformation calculates the four geosynchronous pixel values resulting in four new bands typically denoting brightness (often variation in soil reflectance), greenness (amount of green vegetation), wetness (moisture), and an unspecified other band for which meaning varies depending on the actual land cover (Horne, 2003; Jensen, 2005, 2007; Lasaponara and Masini, 2012a; Lillesand et al., 2008).

We first extracted the study area from the original image using a $1000-\mathrm{m}$ buffer around the lakeshore and then calculated the NDVI and tasseled cap transformation using ERDAS Imagine 2011 software. We stretched all outputs to an unsigned 8-bit format, a scale that would allow the pixel values to be statistically comparable over a uniform range of 256 possible values. The resulting layers were stacked (Fig. 3) to form a single five-band image composed of the NDVI and the four tasseled caps bands. The stacked image represented five variables associated with each pixel to identify spectral anomalies better (Jensen, 2007).

\subsubsection{Unsupervised classification}

Before collecting field data, we first attempted to identify a spectral class associated with archaeological sites in the study area and, second, determine the nature of such a signature. We therefore began with an unsupervised classification of the stacked dataset. An unsupervised classification groups statistically similar spectral signatures in a stacked image without a priori knowledge of the ground cover (Jensen, 2005; Lasaponara and Masini, 2012b; Lillesand et al., 2008; Parcak, 2009). Using ERDAS Imagine, we applied the Iterative Self-Organizing Data Analysis Technique (ISODATA) which groups pixels into a user-specified number of clusters (classes) based on the statistical similarities throughout the stacked image's multidimensional space (Jensen, 2005; Lasaponara and Masini, 2012b; Lillesand et al., 2008). ISODATA requires a user-defined convergence threshold and number of iterations, which were left at the software defaults of 0.95 and 10 , respectively.

The purpose of the unsupervised classification was to assess whether a spectral signature visibly co-occurred within the known archaeological contexts, but this qualitative approach required some decision rules. First, we recognized that the known sites almost certainly do not represent the entire archaeological record in the study area given limited subsurface sampling. We therefore had to assume that an archaeologically-exclusive signature would likely occur beyond the known site areas and within the contexts of unknown sites. We addressed this by looking for a pattern hypothesizing that a cultural class will occur (1) repeatedly with the known sites and neither (2) in an obviously improbable location for locating 


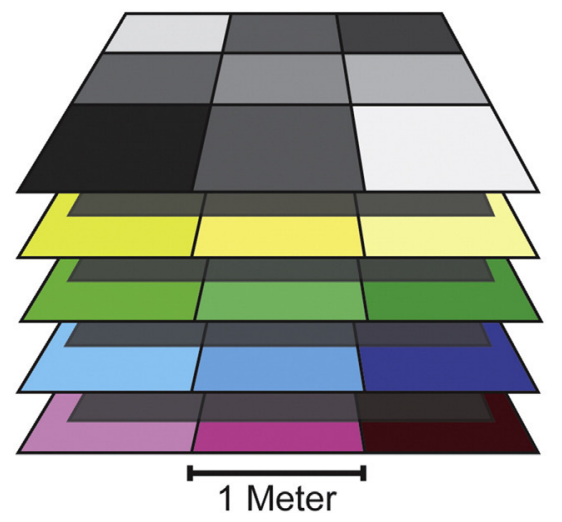

NDVI

Tasseled Cap Band 1 (Brightness)

Tasseled Cap Band 2 (Greenness)

Tasseled Cap Band 3 (Wetness)

Tasseled Cap Band 4 (Other)

Fig. 3. Model of stacked index layers used in the study.

sites (e.g. under water or in the high-energy context of gravel bars) nor (3) evenly distributed across the landscape.

Second, while large, buried features (e.g. stone walls and structures, agricultural fields, road systems, etc.) can significantly alter soil chemistry and the resulting land cover in a patterned, identifiable way (Brophy and Cowley, 2005; Giardino and Haley, 2006; Lasaponara and Masini, 2012c; Maxwell and St. Joseph, 1983; Parcak, 2009; Wilson, 1975), such features would not be expected among mobile Brooks Range hunter-gatherers. However, we expected that a cultural signature could result from two, not-necessarily mutually exclusive, reasons: anthropogenic alteration of the pedology through site activities (e.g. fire, compaction) or local landscape-related conditions that would have appealed to past occupants. If cultural activities such as long-term or reused inhabitation or intensive or repeatedlyused animal processing altered the soil chemistry significantly, we hypothesized that a signature of varying size and shape should fall within the immediate site areas. If local landscape characteristics such as landform, past vegetation, slope, aspect, prevailing winds, soil drainage, etc. influenced human use of the sites, we hypothesized that these would affect modern vegetation patterns associated with the site landforms, although not necessarily in the immediate area in which cultural materials were found.

To identify a cultural signature, we produced a series of unsupervised classifications with an increasing number of statistically-derived classes, and visually interpreted each class in each image using the decisions rules described above. We generated 10-, 20-, 30-, and 40 -class images and found that one spectral class appeared to meet the expectations for cultural association. The signature was most prominent in the 20-class image (Fig. 4) where it generally follows the south-sloping lake shorelines where all the known sites have been discovered and the vegetation/gravel bar ecotones along the Noatak River. No class appeared to correspond directly with the immediate site areas, suggesting that the spectral signature reflects characteristics of the landscape that would have influenced human use rather than anthropogenic variations in pedology.

\subsubsection{Supervised classification}

Having identified an apparent site-related signature, the next step was to identify the nature of that signature and determine whether it represented a particular vegetation pattern indicative of Lake Matcharak's archaeological sites. We field sampled land cover data using the field methods described above. During this process, we also dug $30 \mathrm{~cm}$ shovel tests in several areas with the spectral signature, one of which (AMR-214) tested positive with a chert flake and bone (Figs. 4 and 5a). We used the land cover data to generate a supervised classification to characterize the study area land cover, including individual flora species where possible. Unlike an unsupervised classification that generates statistically-based classes, a supervised classification employs user-defined, representative training areas from knowledge of homogenous land cover. The image analysis software extracts the spectral statistics for each training site, searches for statistical similarities across the image, and then classifies unknown areas according to the statistically closest training site data (Jensen, 2005; Lasaponara and Masini, 2012b; Lillesand et al., 2008; Parcak, 2009). The supervised classification also allowed us to estimate classification accuracy quantitatively, which is not possible with an unsupervised classification.

We used the USGS land use/land cover classification system (Anderson et al., 1976) as a classification template, as it provides level II, general land cover categories for tundra environments - namely shrub, herbaceous, bare, wet, and mixed tundra. We modified the scheme according to uniform vegetation areas that could be identified in the field photos, from which seven classes could be gleaned: birch,

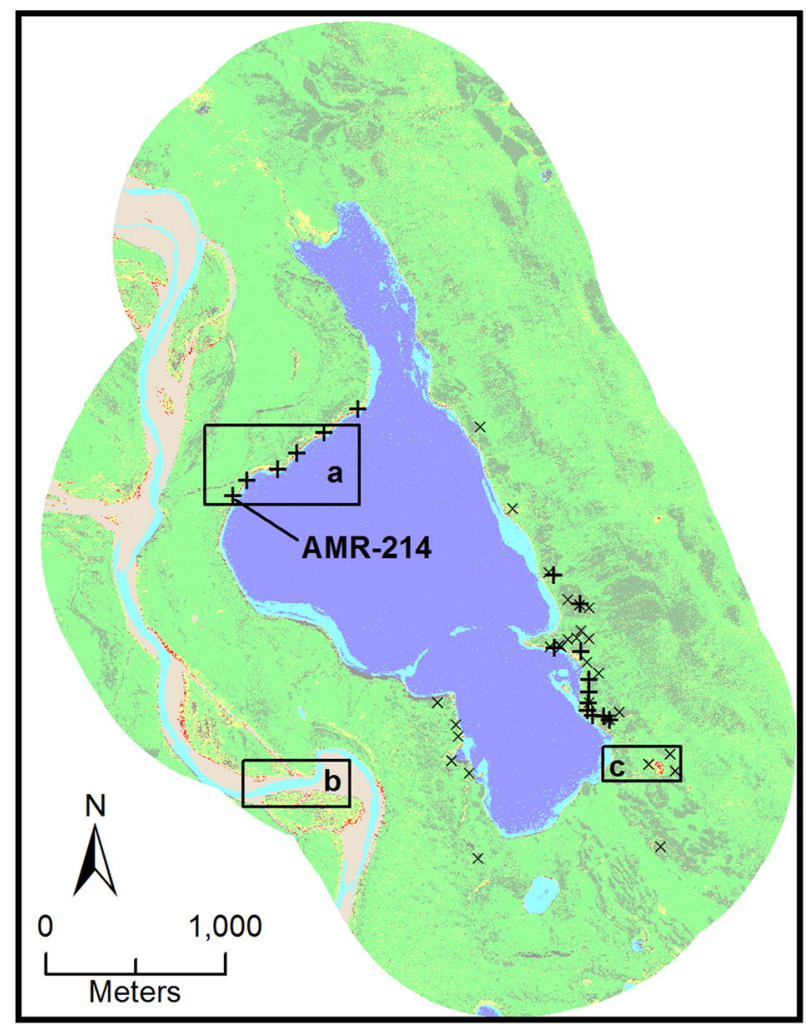

Fig. 4. Unsupervised cultural class (highlighted in red) overlaying the supervised classification (dark blue: deep water; light blue: shallow water; tan: exposed sediments; yellow: willow; dark green: birch; light green: herbaceous tundra). Black crosshairs represent known archaeological sites and black Xs represent all negative shovel tests at the lake. Insets are detailed in Fig. 5. (For interpretation of the references to color in this figure legend, the reader is referred to the web version of this article.) 


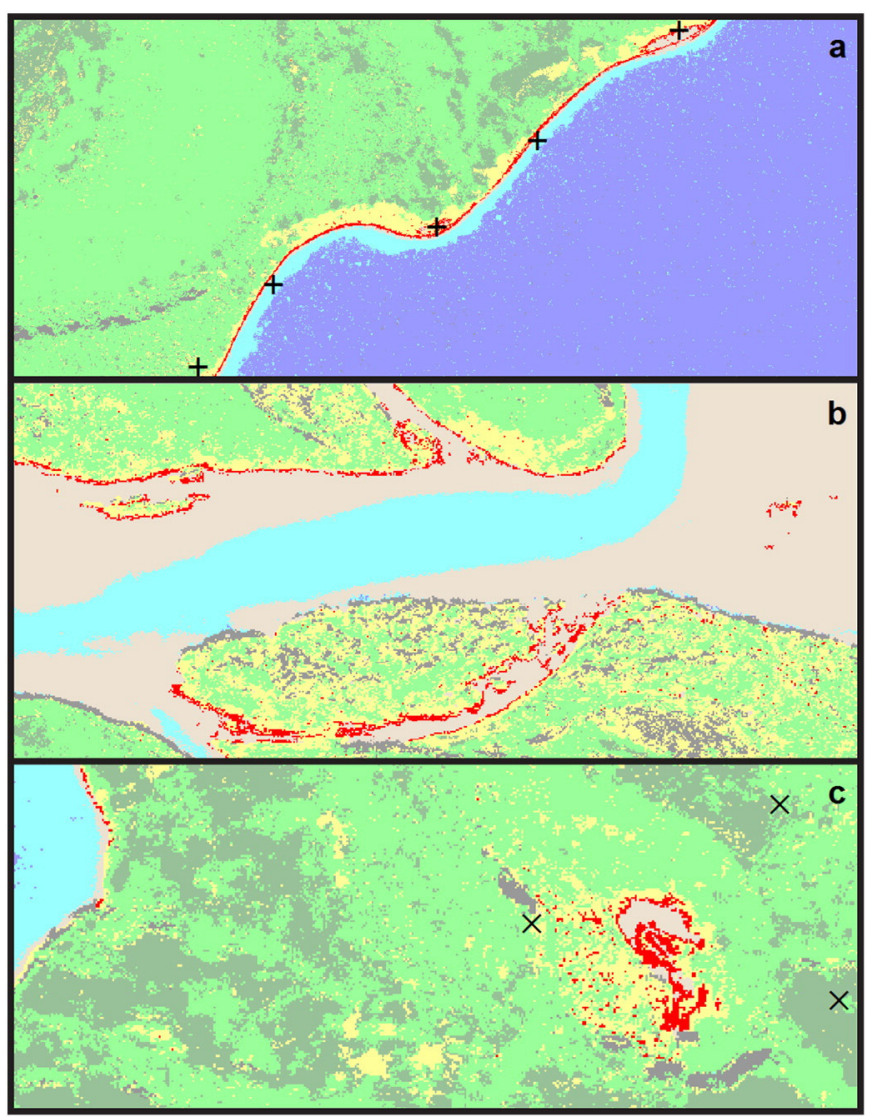

Fig. 5. Representative detail images of the unsupervised class along the willow/exposed sediment ecotone: lake shoreline (a), river bank (b), and the small pond (c). See Fig. 4 for reference, scale, and key.

willow, herbaceous tundra, bare ground, deep water, shallow water, and shadow. Due to insufficient samples of areas dominated by individual grass, forb, sedge, moss, or lichen species, these had to be grouped into the collective herbaceous tundra class as defined by Anderson et al. (1976). Low angle, southerly sunlight cast dark shadows on north-facing slopes in the image and prevented the vegetation canopy in these areas from being identified; a shadow class represented those unidentifiable areas.

When developing the training dataset, shallow and deep water, shadow, and bare ground were easily identified from the IKONOS image. We identified areas of uniform ground cover from field photos, classing them as birch, willow, or herbaceous tundra. We digitized a minimum of 10 training sites for each of the seven classes over the IKONOS image using the field photos and respective GPS points. We extracted spectral data histograms through ERDAS for all five bands from each class to determine the normality of the training data. Distributions tended to be fairly normal, but some bands inconsistently exhibited bimodality. As the maximum likelihood classifier requires normally-distributed data to place each pixel into an available class according to probability, we instead ran the supervised classification tool using the parallelpiped classifier as the primary classification rule. The parallelpiped algorithm uses $n$-bands (in this case five) to produce an $n$-dimensional mean vector from the training data. Each pixel is categorized by the distribution range of each class, and pixels falling outside of all distributions or within overlapping distributions are either classified using another decision rule or left unclassified (Jensen, 2005; Lillesand et al., 2008). We felt it appropriate to use the maximum likelihood classifier as the secondary decision rule given the near-normality of the data.

We then produced a confusion matrix to assess accuracy and errors in the supervised classification quantitatively. We used the same methods for developing the training data to digitize 50 control points for each class in homogenous land cover areas that were not used for the classification. The accuracy assessment results are shown in Table 1, where the columns represent the ground reference point data and the rows represent the classification results from the supervised classification (Congalton and Green, 2009). The bold and regular values in Table 1 indicate correctly and incorrectly classed points, respectively. From these data we were able to calculate the producer's (columns) and user's (rows) accuracies and Kappa statistics shown on the table. The producer's accuracy reflects how accurately the reference areas were classified, whereas the user's accuracy reflects how accurately the classes represent the reference areas (Congalton and Green, 2009; Lillesand et al., 2008). The Kappa statistics measure the accuracy between the classification map and reference data by comparing the difference between the actual and chance agreements between the reference data and the classifier (Jensen, 2005; Lillesand et al., 2008).

The results in Table 1 show some minor issues when classifying willow and herbaceous tundra. The willow user's accuracy suggests an $87 \%$ probability that these pixels actually represent willow ( 3 bare and 2 birch training areas were classified as willow), but the producer's accuracy suggests a $66 \%$ probability of pixels being correctly classified by the reference data. Of the 50 willow reference points, 13 associated pixels were classified as herbaceous tundra, resulting in the lowest (79\%) user's probability that pixels classified as herbaceous tundra actually represent this vegetation type. The lower accuracy may reflect errors in defining the willow training sites, either by including some herbaceous tundra in the training sites or lumping different species of Salix (with different spectral characteristics) into one training class. Despite these errors, the classifications are generally accurate with an overall accuracy of 93.1\% (Kappa $=92.0 \%$ ), reflecting a highresolution vegetation map that can be compared to the known sites and address the nature of the unsupervised cultural class.

\section{Results}

We overlaid the known sites, 20-class unsupervised classification, and supervised classification to compare the cultural signature and known sites with the supervised classes visually. Rather than changes in soil chemistry related to human use of the sites, the unsupervised classification suggested that modern land cover reflects a landscape characteristic that would have appealed to past inhabitants. In order to determine what this class represented, we compared the supervised classification to the unsupervised spectral class (Figs. 4 and 5). The class occurs predominately in three different environments: along the southsloping Lake Matcharak shorelines (Fig. 5a), along the Noatak River gravel bars (Fig. 5b), and in the area of the small pond $250 \mathrm{~m}$ southeast of the lake's southeast corner (Fig. 5c). Upon closer inspection, the lake shore portion of the class falls along the ecotone between dense willow stands and the un-vegetated shoreline. Willow also defines the border between the un-vegetated Noatak River bank and contiguous vegetated land cover in the supervised image. As is the case with the lake shore portion of the class, the Noatak portion also falls along this ecotone. A willow and bare ground ecotone can be seen again at the small dry pond to the lake's southeast corner. Again, the unsupervised spectral class falls along this border. The visual analysis between the unsupervised and supervised images therefore suggests that the unsupervised spectral class reflects where willow transitions to exposed sediments. This corresponds to field knowledge of the area.

The known archaeological sites in the study area are primarily concentrated along terraces in the northwest (Fig. 6a) and southeast (Fig. 6b) regions of the lake. According to the supervised classification, the sites also coincide with some of the densest concentrations of willow in the study area, and especially within $250 \mathrm{~m}$ of the lake shore. Ethnographically, willow was a critical resource in the Brooks Range (Gubser, 1965; Ingstad, 1954) which could have made these areas particularly attractive to prehistoric people if the vegetation 
Table 1

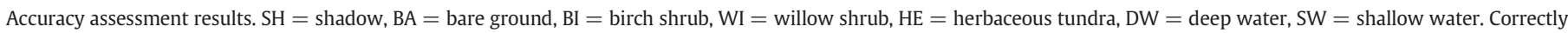
classified control points are in bold. Overall Accuracy $=93.1 \%$ (Kappa $=92.0 \%$ ).

\begin{tabular}{|c|c|c|c|c|c|c|c|c|c|c|}
\hline & & \multicolumn{7}{|c|}{ Reference data } & \multirow[t]{2}{*}{ Row total } & \multirow[t]{2}{*}{ User's accuracy } \\
\hline & & SH & BA & BI & WI & $\mathrm{HE}$ & DW & SW & & \\
\hline \multirow[t]{10}{*}{ Classified data } & $\mathrm{SH}$ & 50 & 0 & 0 & 0 & 0 & 0 & 0 & 50 & $100 \%$ \\
\hline & BA & 0 & 47 & 0 & 0 & 0 & 0 & 0 & 47 & $100 \%$ \\
\hline & BI & 0 & 0 & 48 & 4 & 0 & 0 & 0 & 52 & $92 \%$ \\
\hline & WI & 0 & 3 & 2 & 33 & 0 & 0 & 0 & 38 & $87 \%$ \\
\hline & $\mathrm{HE}$ & 0 & 0 & 0 & 13 & 50 & 0 & 0 & 63 & $79 \%$ \\
\hline & DW & 0 & 0 & 0 & 0 & 0 & 50 & 2 & 52 & $96 \%$ \\
\hline & SW & 0 & 0 & 0 & 0 & 0 & 0 & 48 & 48 & $100 \%$ \\
\hline & Column total & 50 & 50 & 50 & 50 & 50 & 50 & 50 & 350 & \\
\hline & Producer's accuracy & $100 \%$ & $94 \%$ & $96 \%$ & $66 \%$ & $100 \%$ & $100 \%$ & $96 \%$ & & \\
\hline & Kappa statistics & $100 \%$ & $100 \%$ & $91 \%$ & $85 \%$ & $76 \%$ & $96 \%$ & $100 \%$ & & \\
\hline
\end{tabular}

communities were similar. These areas also provide excellent views overlooking the lake and Noatak River valley and are well-drained unlike the water-logged lake outlet to the north and inlet to the south. The south-facing aspects also receive more direct sunlight than north-facing slopes. While factors such as soil drainage or aspect could have influenced past occupants' decisions for selecting these locations over others, these factors also affect where plant species are established. If vegetation in the study area differed significantly in the midHolocene, willow might act as a proxy for desirable site conditions. This would also explain the cultural significance of the unsupervised

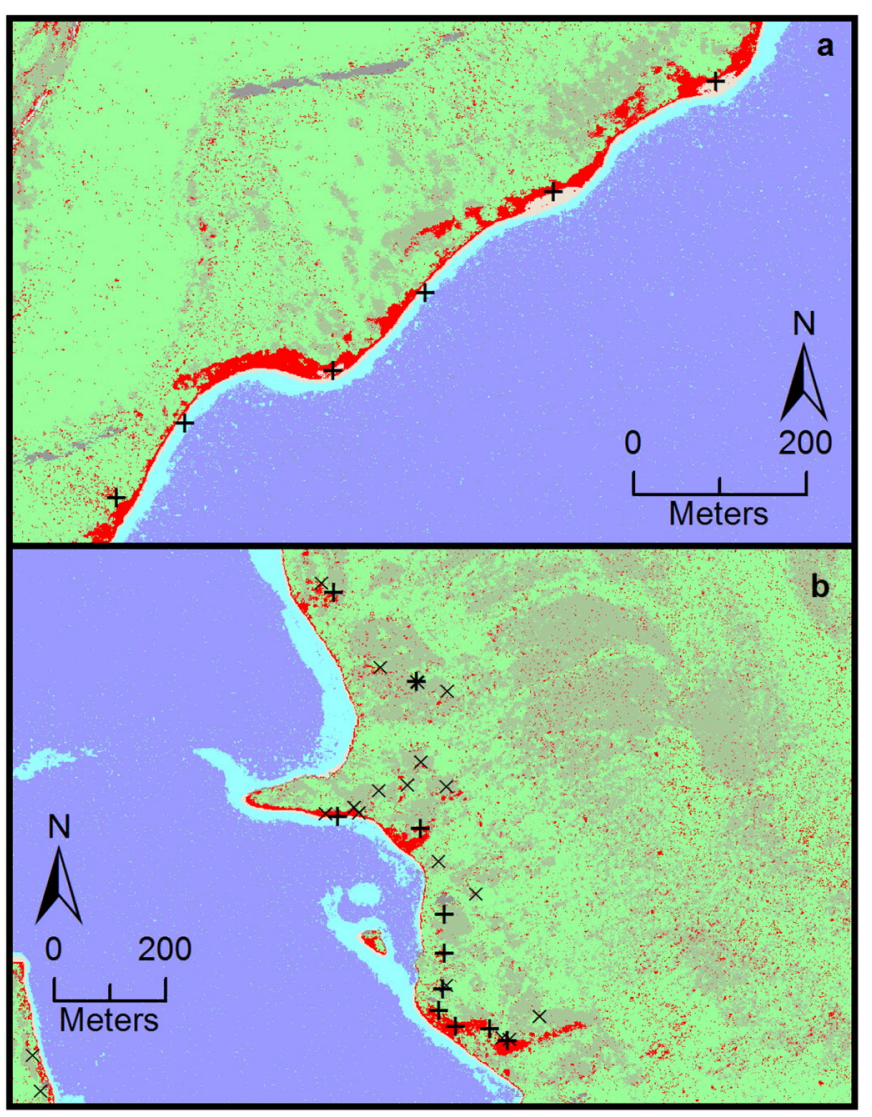

Fig. 6. Detail images of known archaeological sites (black crosshairs) and dense willow stands at Lake Matcharak. Willow has been highlighted red with deep water as dark blue, shallow water as light blue, exposed sediments as tan, birch as dark green, and herbaceous tundra as light green. Black Xs represent negative shovel tests. (For interpretation of the references to color in this figure legend, the reader is referred to the web version of this article.) class that reflects a willow/un-vegetated ecotone. We would not expect this characteristic alone to appeal to past occupants, and instead it likely reflects characteristics of the vegetation and/or landforms that were more desirable.

Dense willow stands are found elsewhere in the supervised image, most notably along the outlet stream flowing north from the lake, surrounding the dry pond to the southeast, along the Noatak River, and above other south-facing hills and terraces, but one would not expect to find sites in all of these locations. The lake outlet is a marshy, waterlogged setting that would make prolonged occupation inhospitable and subsurface testing extremely difficult and costly. Subsurface tests around the small pond failed to recover any cultural material. This is not surprising however, as either of the larger nearby lakes would offer better access to fish and fresh water. Located on flat, dry ground and along a major travel corridor with several important resources readily available, the willow-lined gravel bars along the Noatak River banks would make ideal camp locations; however, these high-energy settings tend to be archaeologically unproductive due to seasonal flow increases and erosion. While these might not be ideal places to locate evidence of past occupation, further testing could be more productive along the willow dominated terraces to the southwest and south-facing hills in the northeast corners of the lake.

\section{Discussion}

\subsection{Willows and past occupation}

The findings suggest that dense willow stands could be a useful proxy for discovering buried hunter-gatherer sites in the Brooks Range. It is important to recognize that this relationship should relate to site function and therefore be indicative of certain site types rather than archaeology in general. Deliberate decisions about landform drainage, slope, local resources, and exposure to direct sunlight or prevailing winds would be important in selecting longterm or regularly re-used contexts such as camps or faunal processing areas. Faunal analysis from the Lake Matcharak Site assemblage indicates a long-term presence during the spring, summer, and fall, possibly exploiting the seasonal migrations of caribou and waterfowl (Tremayne, 2011). Artifacts recovered from the Matcharak Peninsula Site are currently awaiting analysis, yet the presence of multiple taxa from several individuals alongside preliminary evidence of retooling and marrow and bone grease extraction suggest more than an ephemeral, chance occupation of the site. This site represents a place where several distinct and labor-intensive practices co-occurred, possibly within a camp.

If the regional vegetation patterns have remained constant since the mid-Holocene (Anderson and Brubaker, 1994; Anderson et al., 1994; Brubaker et al., 1983; Edwards and Barker, 1994), modern willowdominated areas would have been ideal camp locations in the past. 
Willow was used by Athabascan and Inupiaq people in the region for many purposes including fuel, smoking meat and fish, and the construction of tents, tools, weapons, watercraft, containers, cordage, and other everyday objects (Gubser, 1965; Ingstad, 1954; McKennan, 1965; Nelson, 1986; Vanstone, 1974; West, 1963). However, local vegetation communities around Lake Matcharak may have changed since the mid Holocene as suggested in other tundra ecosystems (Myers-Smith et al., 2011; Sturm et al., 2001; Tape et al., 2006). In this case, modern willow growth might be attributed to other factors that made these places attractive to prehistoric human inhabitants (Warren, 1990; Whitley, 2006). Willows are generally associated with moist habitats in northern latitudes (Brayshaw, 2006). There are many species of Salix in northern Alaska, and these occur in many different ecosystems including marshes, floodplains, sand dunes, talus slopes, tundra, and alpine settings. However, a common attribute of willow is that it rapidly colonizes and thrives in unstable environments, including those disturbed by rivers, fire, frost, and humans (Argus, 1973). Further investigations should address the reasons for the connection between prehistoric sites and modern willow-dominated areas.

\subsection{Implications for future surveys}

These implications are most relevant for situations when site discovery, rather than a more complete areal sampling, is of the essence. It is expensive, arduous, and time consuming to develop cultural resource inventories for vast and remote Arctic areas. In light of shrinking budgets, archaeologists are limited in the ground that they can thoroughly cover in the limited timeframes allotted toward summer survey projects. Such limitations present problems for systematic and random sampling strategies, which are concerned with determining not only where artifacts are, but also where they are not.

In the case of Lake Matcharak, nearly all the known sites are buried and obscured by vegetation, and very little was found through standard reconnaissance techniques. Only through repeated visits to Lake Matcharak did time permit more intensive subsurface testing that revealed the majority of sites known today. The significant finds at Lake Matcharak were largely a matter of luck, but the methods outlined in this paper have potential for contributing to a more efficient means for discovering sites in the future. The remote sensing techniques outlined here would be most useful in settings where surface evidence of buried archaeological sites is lacking. In the cases of the Matcharak Lake and Matcharak Peninsula sites, these sites with scant surface evidence were later found to contain thousands of well-preserved faunal and lithic artifacts and features; therefore, what is found on the ground and in minuscule shovel tests poorly indicate the archaeological record concealed below. These remote sensing techniques contribute tools that can be built upon to overcome this problem by revealing phenomena in the landscape that cannot be perceived with the naked eye and yet may be archaeologically relevant. In turn, archaeologists can then focus on higher-probability areas and allocate more time to subsurface testing.

For the purpose of inventorying cultural resources in areas such as state and federal public lands, archaeologists are adopting hybrid methods to maximize areas that can be covered and target areas in which sites will more likely be located. Although such methods almost certainly cannot produce complete or accurate representations of cultural activities in the area under investigation, predictive methods may help archaeologists devote field time to finding sites and assessing threats that may disturb or destroy the archaeological contexts. For example, recent climate change has impacted polar regions particularly (ACIA, 2005; Anisimov et al., 2007), and, in turn, permafrost degradation and increased erosion threaten archaeological preservation in high latitudes. As time is of the essence, predictive methods such as those outlined in this paper have the potential for supplementing future field surveys to locate and record more archaeological data before they are gone forever.

\subsection{Errors and limitations}

It is also important to recognize the limitations to the findings of this analysis. First, more subsurface sampling is needed. The known sites only represent those that have been identified so far, with an emphasis in areas close to the excavations at the Matcharak Lake and Peninsula sites. As past surveys have focused more on locating sites rather than on unbiased sampling designed to create statistically-valid models of archaeological site distribution, more intensive subsurface testing at Lake Matcharak could evidence past human activities beneath other land cover types around the lake. Second, it is possible that dense willow growth is attributable to a form of disturbance in these areas, such as terrace erosion. As several sites were identified from artifacts exposed by terrace erosion, willow may only be an indicator of how sites were found, but not why they were located there. Third, one must bear in mind that season and local conditions affect vegetation color patterns, even among similar species. These factors must be taken into consideration when applying these methods to other datasets. When one classification is applied to multiple datasets, the imagery should have been acquired in the same time of the year, if not the same date, and classifications should be limited at least to similar ecoregions. Although beyond the scope of this project, comparing imagery from different seasons (e.g. Beck et al., 2007) and vegetation indices (e.g. Bennett et al., 2012) could address differences in seasonal reflectance patterns. This can be difficult in the Arctic, however, due to the limited opportunities for cloud-free days during the brief window between late-spring thaw and early fall snowfall (Hope and Stow, 1995).

The methods outlined here could also use some revision. First, the training data sampling strategy could have been improved. In hindsight, it would have been better to use the unsupervised classification also to identify homogenous land cover sampling locations. While the accuracy assessment suggests that the methods we used were adequate for producing accurate training data, an unsupervised classification might have allowed us to travel straight to homogenous land cover classes, identify and record them in the field, and avoid time analyzing photos later. This could have also helped narrow down more species-level training classes and produce a supervised classification that better reflects vegetation diversity in the study area. Second, the use of more accurate GPS units would have provided better site and ground reference data.

\subsection{Avenues for further research}

More subsurface sampling is needed at Lake Matcharak. If more systematic testing at Lake Matcharak reveals that sites are concentrated in areas presently dominated by willow, the next question that must be pursued is why? Sampling for phytoliths and plant macrofossils within the sites and their surrounding areas might help explain if willow has remained constant at those locations or if it has come to replace another dominant vegetation type. Also, continued testing at the sites and analysis of the artifacts retrieved from AMR-196 could help explain when and why people chose to locate at Lake Matcharak and at those sites specifically. Landform shape might have also influenced past decisions, so VHR digital elevation models and LIDAR might aid in future analyses as they become available. As the orientations of terraces on which sites are located appear to be consistent across Lake Matcharak, aspect is a variable that could be incorporated into future applications of these methods. The methods outlined in this paper could also be applied to imagery of other lake sites in the Brooks Range to test if willow-dominated sites, or some other vegetation community, are common or unique to Lake Matcharak. Some prime candidates would be Desperation, Burial, Kaiyak, and Feniak Lakes with their large, welldocumented village sites. It could also be advantageous to apply these methods to spectrally-richer and higher-resolution imagery such as Quickbird, Geoeye, and Worldview. Finally, this study 
focused on identifying a spectral phenomenon associated with archaeological sites, but how to operationalize these findings toward site prospecting falls beyond the scope of this paper. A next step is to find a repeatable method for incorporating these findings and methods into predictive models.

\section{Conclusions}

The results of this pilot study suggest that prehistoric, seasonal camp sites at Lake Matcharak appear associated with modern stands of dense willow growth. Pixel-based analysis methods can locate these areas using $1 \mathrm{~m}$ resolution IKONOS imagery. While the unsupervised classification reflected a unique spectral anomaly reflecting the ecotone between willow and bare, un-vegetated ground, the supervised classification suggested an association with willow. A confusion matrix with an overall accuracy of 93\% confirms the land cover distribution, which has also been consistent with field observations. The willow-archaeology association may represent prehistoric human habitation near a vital resource, or willow may act as a proxy for other landform characteristics that would have attracted past occupants. These methods would be most useful when incorporated into predictive models used to supplement field survey planning for locating archaeological sites more efficiently. We hope that this study will stimulate future applications of satellite data to North American archaeology and hunter-gatherer landscapes. There is great potential for VHR data to tell us about not only where sites can be found but also the lives of the past occupants.

\section{Acknowledgments}

This paper is the product of a two year undergraduate honors project at Central Washington University. We would first like to thank the Central Washington University Science Honors Research Program and director Audrey Huerta for providing the research opportunity, guidance, and part of the funding for the project. We would like to extend a very special thanks to Jeff Rasic for his help with developing and guiding the project and his valuable input throughout the editing process. To the National Park Service, thank you for providing project support as well as the necessary datasets. Special thanks to Ian Buvit from the CWU McNair Scholars Program for his guidance and input as a co-mentor for the project. Special thanks to Tim Williams for his assistance and endless enthusiasm during our 14 hour hike until 1:30 a.m. to collect data. Thanks to Chris Ciancibelli and Phoebe Gilbert for their patience during the time spent on this project while excavating at Lake Matcharak in 2011. We would also like to thank Jennifer Lipton from the CWU Department of Geography for her valuable input and instruction that helped to make this project possible. Finally, thanks to Jamie Clark from the University of Alaska Fairbanks Department of Anthropology and Adam Freeburg from the National Park Service for their assistance and attention to detail during the editing process.

\section{References}

ACIA, 2005. Arctic Climate Impact Assessment. Cambridge University Press, New York.

AK I\&M Inventory Program, 2009. Arctic network land cover map 2008, national park service, Anchorage, AK. Geospatial Dataset-2171592.

Alexakis, D., Sarris, A., Astaras, T., Albanakis, K., 2009. Detection of neolithic settlements in Thessaly (Greece) through multispectral and hyperspectral satellite imagery. Sensors 9 (2), 1167-1187.

Alexakis, D., Sarris, A., Astaras, T., Albanakis, K., 2011. Integrated GIS, remote sensing and geomorphologic approaches for the reconstruction of the landscape habitation of Thessaly during the neolithic period. J. Archaeol. Sci. 38 (1), 89-100.

Anderson, D.D., 1988. Onion portage: the archaeology of a stratified site front the Kobuk River, Northwest Alaska. Anthropol. Pap. Univ. Alaska 22 (1-2), 1-163.

Anderson, P.M., Brubaker, L.B., 1994. Vegetation history of northcentral Alaska: a mapped summary of late-quaternary pollen data. Quat. Sci. Rev. 13 (1), 71-92.

Anderson, J.R., Hardy, E.E., Roach, J.T., Witmer, R.E., 1976. A Land Use and Land Cover Classification System for Use with Remote Sensor Data, Geological Survey Professional Paper 964. Depatment of the Interior, United States Government Printing Office, Washington D.C
Anderson, P.M., King, M.L., Lozhkin, A.V., Brubaker, L.B., Hu, F.S., 1994. Late-Pleistocene and early-Holocene vegetation of Beringia: implications for archaeological interpretations. Curr. Res. Pleistocene 11, 111-113.

Anisimov, O.A., Vaughan, D.G., Callaghan, T.V., Furgal, C., Marchant, H., Prowse, T.D. Vilhjálmsson, H., Walsh, J.E., 2007. Polar regions (Arctic and Antarctic). In: Parry, M.L., Canziani, O.F., Palutikof, J.P., Linden, P.J.V.D., Hanson, C.E. (Eds.), Climate change 2007: impacts, adaptation and vulnerability. Contribution of Working Group II to the Fourth Assessment Report of the Intergovernmental Panel on Climate Change. Cambridge University Press, Cambridge, pp. 653-685.

Argus, G.W., 1973. The Genus Salix in Alaska and the Yukon, National Museums of Canada, Ottawa.

Beck, A., Philip, G., Abdulkarim, M., Donoghue, D., 2007. Evaluation of Corona and Ikonos high resolution satellite imagery for archaeological prospection in western Syria. Antiquity 81 (311), 161-175.

Bennett, R., Welham, K., Hill, R.A., Ford, A.L.J., 2012. The application of vegetation indices for the prospection of archaeological features in grass-dominated environments. Archaeol. Prospect. 19 (3), 209-218.

Brayshaw, T.C., 2006. Catkin-bearing Plants of British Columbia, Royal British Columbia Museum, Victoria.

Brophy, K., Cowley, D., 2005. From the Air: Understanding Aerial Archaeology Tempus, Stroud.

Brubaker, L.B., Garfinkee, H.L., Edwards, M.E., 1983. A late Wisconsin and Holocene vegetation history from the central Brooks Range: implications for Alaskan palaeoecology. Quat. Res. 20 (2), 194-214.

Buck, P.E., Sabol, D.E., Gillespie, A.R., 2003. Sub-pixel artifact detection using remote sensing. J. Archaeol. Sci. 30 (8), 973-989.

Clark, D.W., 1992. The archaic in the extreme Northwest of North America. Rev. Arqueol Am. (5), 71-99.

Congalton, R.G., Green, K., 2009. Assessing the Accuracy of Remotely Sensed Data: Principles and Practices. 2 ed. CRC Press, Boca Raton.

De Laet, V., Paulissen, E., Waelkens, M., 2007. Methods for the extraction of archaeologica features from very high-resolution Ikonos-2 remote sensing imagery, Hisar (southwest Turkey). J. Archaeol. Sci. 34 (5), 830-841.

De Laet, V., van Loon, G., Van der Perre, A., Deliever, I., Willems, H., 2015. Integrated remote sensing investigations of ancient quarries and road systems in the Greater Dayr al-Barshā Region, Middle Egypt: a study of logistics. J. Archaeol. Sci. 55, 286-300

Deroin, J.-P., Téreygeol, F., Heckes, J., 2011. Evaluation of very high to medium resolution multispectral satellite imagery for geoarchaeology in arid regions - case study from Jabali, Yemen. J. Archaeol. Sci. 38 (1), 101-114.

Digital Globe, 2015. IKONOS Data Sheet. https://www.digitalglobe.com/sites/default/files/ DG_IKONOS_DS.pdf (Accessed January 17, 2015).

Edwards, M.E., Barker Jr., E.D., 1994. Climate and vegetation in northeastern Alaska 18,000 yr B.P.-present. Palaeogeogr. Palaeoclimatol. Palaeoecol. 109 (2-4), 127-135.

Esdale, J.A., 2008. A current synthesis of the Northern Archaic. Arct. Anthropol. 45 (2), 3-38.

Gallant, A.L., Binnian, E.F., Omernik, J.M., Shasby, M.B., 1995. Ecoregions of Alaska, U.S. Geological Survey Professional Paper 1567. US Government Printing Office, Washington D.C

Giardino, M., Haley, B.S., 2006. Airborne remote sensing and geospatial analysis In: Johnson, J.K. (Ed.), Remote Sensing in Archaeology. University of Alabama, Tuscaloosa, pp. 47-77.

Giddings, J.L., 1951. The Denbigh Flint Complex. Am. Antiq. 16 (3), 193-203.

Giddings, J.L., 1964. The Archaeology of Cape Denbigh. Brown University Press, Providence.

Grøn, O., Palmér, S., Stylegar, F., Esbensen, K., Kucheryavski, S., Aase, S., 2011. Interpretation of archaeological small-scale features in spectral images. J. Archaeol. Sci. 38 (9), 2024-2030.

Gubser, N.J., 1965. The Nunamiut Eskimos: Hunters of Caribou. Yale University Press, New Haven.

Hamilton, T.D., 2009. Guide to Surficial Geology and River-Bluff Exposures, Noatak National Preserve, Northwestern Alaska, Scientific Investigations Report 2008-5125 U.S. Geological Survey.

Hope, A., Stow, D., 1995. Shortwave reflectance properties of Arctic Tundra. In: Reynolds J., Tenhuenen, J. (Eds.), Landscape Function and Disturbance in Arctic Tundra. Springer, Heidelberg, pp. 155-164.

Horne, J., 2003. A Tasseled Cap Transformation for Ikonos Images, May 2003 Meeting of ASPRS.

Ingstad, H., 1954. Nunamiut: Among Alaska's Inland Eskimos. Unwin Brothers Limited, London.

Irving, W.N., 1964. Punyik Point and the Arctic Small Tool Tradition. Department of Anthropology, University of Wisconson, Madison.

Jensen, J.R., 2005. Introductory Digital Image Processing: A Remote Sensing Perspective. 3 ed. Pearson Prentice Hall, Upper Saddle River.

Jensen, J.R., 2007. Remote Sensing of the Environment: An Earth Resource Perspective. 2 ed. Pearson Prentice Hall, Upper Saddle River.

Lasaponara, R., Masini, N., 2007. Detection of archaeological crop marks by using satellite QuickBird multispectral imagery. J. Archaeol. Sci. 34 (2), 214-221.

Lasaponara, R., Masini, N., 2011. Satellite remote sensing in archaeology: past, present and future perspectives. J. Archaeol. Sci. 38 (9), 1995-2002.

Lasaponara, R., Masini, N., 2012a. Image enhancement, feature extraction and geospatial analysis in an archaeological perspective. In: Masini, N., Lasaponara, R. (Eds.), Satellite Remote Sensing. Springer, Netherlands, pp. 17-63.

Lasaponara, R., Masini, N., 2012b. Pattern recognition and classification using VHR data for archaeological research. In: Masini, N., Lasaponara, R. (Eds.), Satellite Remote Sensing. Springer, Netherlands, pp. 65-85.

Lasaponara, R., Masini, N., 2012c. Remote sensing in archaeology: from visual data interpretation to digital data manipulation. In: Masini, N., Lasaponara, R. (Eds.) Satellite Remote Sensing. Springer, Netherlands, pp. 3-16. 
Lillesand, T.M., Kiefer, R.W., Chipman, J.W., 2008. Remote Sensing and Image Interpretation. 6 ed. John Wiley and Sons, New York.

Luo, L., Wang, X., Liu, C., Guo, H., Du, X., 2014. Integrated RS, GIS and GPS approaches to archaeological prospecting in the Hexi Corridor, NW China: a case study of the royal road to ancient Dunhuang. J. Archaeol. Sci. 50, 178-190.

Masini, N., Lasaponara, R., 2007. Investigating the spectral capability of QuickBird data to detect archaeological remains buried under vegetated and not vegetated areas. J. Cult. Herit. 8 (1), 53-60.

Maxwell, G., St. Joseph, J.K.S., 1983. The Impact of Aerial Reconnaissance on Archaeology. Council for British Archaeology, London.

McKennan, R.A., 1965. The Chandalar Kutchin. Arctic Institute of North America, Montreal.

Myers-Smith, I.H., Forbes, B.C., Wilmking, M., Hallinger, M., Lantz, T., Blok, D., Tape, K.D., Macias-Fauria, M., Sass-Klaassen, U., Lévesque, E., Boudreau, S., Ropars, P., Hermanutz, L., Trant, A., Collier, L.S., Weijers, S., Rozema, J., Rayback, S.A., Schmidt, N.M., Schaepman-Strub, G., Wipf, S., Rixen, C., Ménard, C.B., Venn, S., Goetz, S. Andreu-Hayles, L., Elmendorf, S., Ravolainen, V., Welker, J., Grogan, P., Epstein, H.E. Hik, D.S., 2011. Shrub expansion in Tundra ecosystems: dynamics, impacts and research priorities. Environ. Res. Lett. 6 (4), 1-15.

Nelson, R.K., 1986. Hunters of the Northern Forest: Designs for Survival among the Alaskan Kutchin. 2 ed. University of Chicago Press, Chicago.

Oltean, I., Abell, L., 2012. High-resolution satellite imagery and the detection of buried archaeological features in ploughed landscapes. In: Masini, N., Lasaponara, R. (Eds.) Satellite Remote Sensing. Springer, Netherlands, pp. 291-305.

Parcak, S.H., 2009. Satellite Remote Sensing for Archaeology. 1 ed. Routledge, New York

Saturno, W., Sever, T.L., Irwin, D.E., Howell, B.F., Garrison, T.G., 2007. Putting us on the map: remote sensing investigation of the ancient Maya landscape. In: Wiseman, J., El-Baz, F. (Eds.), Remote Sensing in Archaeology. Springer, New York, pp. 137-160.
Slaughter, D.C., 2005. Radiocarbon dating the arctic small tool tradition in Alaska, Alaska. J. Anthropol. 3 (2), 117-134.

Sturm, M., Racine, C., Tape, K., 2001. Climate change: increasing shrub abundance in the Arctic. Nature 411 (6837), 546-547.

Tape, K.E.N., Sturm, M., Racine, C., 2006. The evidence for shrub expansion in Northern Alaska and the Pan-Arctic. Glob. Chang. Biol. 12 (4), 686-702.

Tremayne, A.H., 2011. An analysis of faunal remains from a Denbigh Flint Complex Camp at Matcharak Lake, Alaska. Arct. Anthropol. 48 (1), 33-53.

Tremayne, A.H., 2015. The design of Arctic small tool tradition toolkits: an example from Matcharak Lake, Alaska. N. Am. Archaeol. 36 (1), 1-31.

Trier, Ø.D., Larsen, S.Ø., Solberg, R., 2009. Automatic detection of circular structures in high-resolution satellite images of agricultural land. Archaeol. Prospect. 16 (1), 1-15.

Vanstone, J.W., 1974. Athapaskan Adaptations: Hunters and Fishermen of the Subarctic Forests. Harlan Davidson, Arlington Heights.

Warren, RE. 1990. Predictive modeling in archaeology: a primer. In: Allen, K.M.S., Green, S.W., Zubrow, E.B.W. (Eds.), Interpreting Space: GIS and Archaeology. Taylor and Francis, New York, pp. 90-111.

West, F., 1963. The Netsi Kutchin: An Essay in Human Ecology. Department of Geography and Anthropology, Lousiana State University, Ann Arbor, p. 419.

Whitley, T.G., 2006. Predictive modeling in a homogenous environment: an example from the Charleston Naval Weapons Station, South Carolina. In: Mehrer, M.W., Wescott, K.L. (Eds.), In GIS and Archaeological Site Location Modeling. CRC, Boca Raton, pp. 335-392.

Wilson, D.R., 1975. Aerial Reconnaissance for Archaeology. Council for British Archaeology, London.

Workman, W.B., 1978. Prehistory of the Aishihik-Kluane Area, Southwest Yukon Territory, Archaeological Survey of Canada, National Museum of Man, Ottawa. 